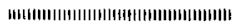

論説

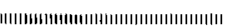

含窒素オーステナイト系ステンレス鋼の

冷間加工材における時効挙動

磯部 晋*, 岡部道生**

\title{
Aging Behavior of Cold Worked Austenitic Stainless Steels with Nitrogen
}

Susumu Isobe, Michio Okabe

\begin{abstract}
Synopsis
Non-magnetic austenitic stainless steels with $\mathrm{N}$ were strengthened by micro addition of $\mathrm{Nb}$ and $\mathrm{V}$, cold working and precipitation hardening hereafter. The strength of steels as solution treated are enhanced through solid solution strengthening by $\mathrm{N}$ and also through grain refining by $\mathrm{Nb}$ and $\mathrm{V}$ nitrides. During aging after cold working, the carbo-nitride, $\mathrm{M}_{23}(\mathrm{C}, \mathrm{N})_{6}$, precipitates intragranularly and increases strength, especially $0.2 \%$ proof stress. An alloy with $0.1 \mathrm{C}, 18 \mathrm{Cr}, 12 \mathrm{Ni}, 0.1 \mathrm{~V}, 0.25 \mathrm{~N}$ shows the tensile strength of $200 \mathrm{kgf} / \mathrm{mm}^{2}$ up and the permeability under 1.01 after $80 \%$ cold working and aging for lh at $500^{\circ} \mathrm{C}$.
\end{abstract}

\section{1. 緒言}

近年，各種の含窒素 $(\mathrm{N})$ オーステナイト采ステ ンレス鋼が，高強度・高耐食材料として実用化さ れている。これらの鋼種では, Nによる固溶強化 と $\mathrm{Nb}$ 等の添加による結唱粒微細化により強度を 得て抢り，その強化機構については従来から広く 研究されている1) 。しかしこれれ冷間加工を施 しても，17-7PH 等のセミオーステナイト系析出 硬化型ステンレス鋼や高 Cの構造用鋼の強度に は達せず, より強度の高い含Nステンレス鋼が要 求されている。

昭和 60 年 3 月 18 日 受付

*大同特殊鋼的中央研究所

**大同特殊鋼物中央研究所，工博
含 $\mathrm{N}$ ステンレス鋼を更に強化する万法として 時効処理が考えられる。N を添加していない通常 のステンレス鋼の時効処理については, 鋭敏化処 理に関連した数多くの研究がある゙ 上れば9，冷間加工を施したステンレス鋼を低温 で時効すると，固溶化処理材では粒界に析出する $\mathrm{M}_{23} \mathrm{C}_{6}$ が粒内微細析出し, 粒界腐食感受性が低 下する。この析出形態の変化は, 冷間加工によっ てもたらされたものである。低温の時効処理は， 比較的 C 量の多い:シネ用ステンレス鋼において は強化に積極的に利用され，ブルーイング処理と してバネ限界值の上昇に役立っている ${ }^{100,11)}$ 。含 $\mathrm{N}$ ステンレス鋼では，固溶化処理村の鋭敏化の研究 はあるすのの, 冷間加工材の時効処理に関する研 究はほとんどない。析出挙動については，クリー ブ変形により導入された転位上への $\mathrm{M}_{23}(\mathrm{C}, \mathrm{N})_{6}$ 
や $\mathrm{NbCrN}$ の優先析出が観察されているだけであ

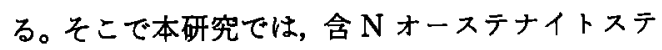
ンレス鋼において, 冷間加工材の時効硬化挙動を 調查し, 炭空化物の粒内粪細析出による強度上昇 を検討することにした。

一方, オーステナイト系ステンレス鋼は, 非磁 性鋼としても多く用いられる。しかし, 強度を上 昇させるために冷間加工を施すと, 加工誘起マル テンサイトが生成し，透磁率が上昇する。N $\mathrm{N}$ は 同様加工誘起マルテンサイトを抑制する作用が強

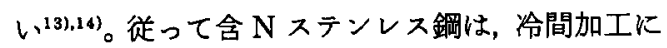
よる透磁率の上昇が少ない, 高強度の非磁性鋼に 適している。そこで本研究では，高強度化の検討 に加光，冷間加工材の透磁率に及ぼすNの影響を 調査することにした。更にこれらの知見に基づ き非磁性高強度ステンレス鋼を試作し，特性を調 查した。

\section{2. 供試材及ひ実験方法}

\section{1 供 試 材}

Table 1 に供試材の化学組成を示す。供試材は, 代表的なステンレス鋼である $18 \mathrm{Cr}-10 \mathrm{Ni}$ 鋼（A
鋼)を基本組成にして，N，Nb，Vを变化させた。 $\mathrm{B}$ 鋼は, $\mathrm{N}$ 添加の影響を調べるための $\mathrm{N}$ 単独添加 鋼である。

供試材は，真空誘導炉を用い $50 \mathrm{~kg}$ 鋼塊に溶製 した後，直径 $10 \mathrm{~mm}$ の棒状に鍛造・压延した。こ れに, $1050^{\circ} \mathrm{CWC}$ の固容化処理を施し, 線引に上 り最大 $80 \%$ の減面率の冷間加工を加えた後, $300 \sim 700^{\circ} \mathrm{C}, 1 \mathrm{~h}$ の時効を行ない, 試験に供した。

\section{2 主な実験方法}

・機械的性質：常温引張試験及びビッカース硬 さ測定（荷重 1kgf）を実施した。

・ミクロ組織観察：10\%シュウ酸により電解腐 食した試料を観察し，結晶粒度を測定した。 さらに，抽出レブリカ法による透過電子䫒微 鏡観察を行い炭窒化物を調查した。

・析出物の同定：10\%塩酸ーメタノールにより 析出物を電解抽出し, X 線回折により同定し た。電解抽出は, 電流密度 $20 \mathrm{~mA} / \mathrm{cm}^{2}$ で行い, 溶夜を遠心分離後, $0.1 \mu \mathrm{m}$ のメッシニのフィ ルターにより吸引ろ過して残渣を回収した。 $\mathrm{X}$ 線回折は, $\mathrm{CoK}$ 線を用いて出力 $70 \mathrm{kV} \times$ 40mA で測定した。

Table 1 Chemical composition of steels. (wt\%)

\begin{tabular}{c|c|c|c|r|c|c|c|c}
\hline Steel & $\mathrm{C}$ & $\mathrm{Si}$ & $\mathrm{Mn}$ & $\mathrm{Ni}$ & $\mathrm{Cr}$ & $\mathrm{Nb}$ & $\mathrm{V}$ & $\mathrm{N}$ \\
\hline $\mathrm{A}$ & 0.05 & 0.51 & 2.06 & 9.89 & 18.22 & - & - & - \\
\hline $\mathrm{B}$ & 0.05 & 0.50 & 2.06 & 10.23 & 18.23 & 0.02 & - & 0.17 \\
\hline $\mathrm{C}$ & 0.05 & 0.52 & 2.09 & 9.92 & 18.48 & 0.05 & - & 0.11 \\
\hline $\mathrm{D}$ & 0.05 & 0.47 & 2.20 & 9.97 & 18.70 & 0.05 & - & 0.19 \\
\hline $\mathrm{E}$ & 0.05 & 0.53 & 2.12 & 9.98 & 18.54 & 0.10 & - & 0.12 \\
\hline $\mathrm{F}$ & 0.05 & 0.61 & 2.08 & 9.96 & 18.46 & 0.10 & - & 0.20 \\
\hline $\mathrm{G}$ & 0.05 & 0.40 & 2.15 & 9.98 & 18.49 & 0.26 & - & 0.09 \\
\hline $\mathrm{H}$ & 0.05 & 0.62 & 2.14 & 10.00 & 18.50 & 0.28 & - & 0.21 \\
\hline $\mathrm{I}$ & 0.05 & 0.58 & 2.14 & 10.05 & 18.85 & 0.04 & - & 0.29 \\
\hline $\mathrm{J}$ & 0.05 & 0.56 & 2.06 & 9.97 & 18.51 & - & 0.10 & 0.19 \\
\hline $\mathrm{K}$ & 0.05 & 0.58 & 2.09 & 10.02 & 18.59 & - & 0.19 & 0.20 \\
\hline $\mathrm{L}$ & 0.05 & 0.55 & 2.05 & 10.03 & 18.59 & - & 0.28 & 0.20 \\
\hline $\mathrm{M}$ & 0.05 & 0.51 & 2.06 & 9.95 & 18.48 & 0.10 & 0.02 & 0.09 \\
\hline $\mathrm{N}$ & 0.05 & 0.51 & 2.08 & 10.01 & 18.51 & 0.10 & 0.04 & 0.09 \\
\hline $\mathrm{O}$ & 0.06 & 0.50 & 2.07 & 9.95 & 18.44 & 0.10 & 0.10 & 0.08 \\
\hline
\end{tabular}


・透磁率：直径 $5 \mathrm{~mm}$, 長さ $5 \mathrm{~mm}$ の試料を用い て振動試料型磁力計法により，外部磁界 $100 \mathrm{Oe}$ で測定した。

\section{3. 実験結果及び考察}

\section{1 結晶粒径に及ほす固溶化処理温度の影} 響

オーステナイト系ステンレス鋼の強度は, 結晶 粒径に大きく依存するため，結晶粒径に及ぼす固 溶化処理温度の影響を調查した。Fig. 1 にV 添加 鋼を1 $000 \sim 1200^{\circ} \mathrm{C}$, $1 \mathrm{~h}$ の固溶化処理をした時の 結晶粒径の变化を示す。また Fig. 2 は，固溶化処 理状態で残存している末固溶炭窒化物の面積率を 測定した例である。ただし，面積率は抽出レブリ カ観察により求めたため，過大に評価した値とな っている。結晶粒は，固容化処理温度の上昇に伴 い急激に粗大化し, 逆に面積率は大きく減少する。 すなわち，未固溶炭窒化物が粒界移動の障害とな って粒成長を抑制していることがわかる。この結 果より，結晶粒が粗大化せす，炭窒化物が比較的 固溶する $1050^{\circ} \mathrm{C} ， 1 \mathrm{~h}$ を固容化処理条件として選 定した。

Fig. 3 に, $1050^{\circ} \mathrm{C}$, $1 \mathrm{~h}$ の固容化処理を施した時 の結晶粒径と $\mathrm{Nb} ， \mathrm{~V}$ の添加量との関保を示す。 $\mathrm{Nb}$ と V とを比べると，結晶粒成長抑制効果は $\mathrm{Nb}$ の方が若干大きいことがわかる。第 2 相があ る時の結晶粒成長に関する古典的な扱いによれ

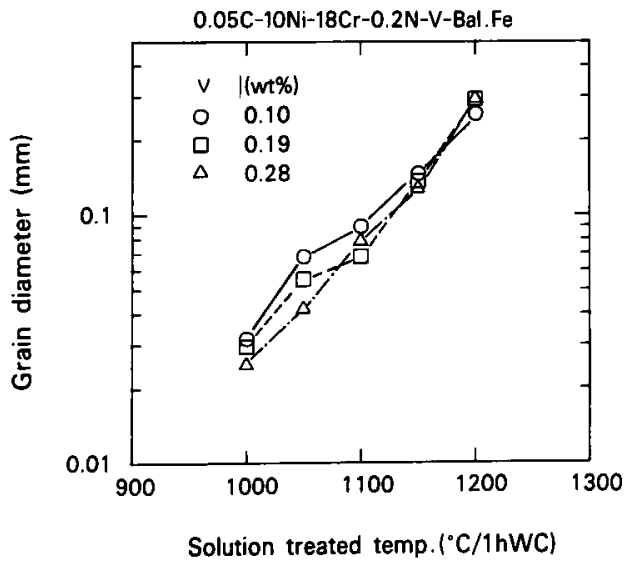

Fig. 1. Effect of solution treated temperature on recrystallized grain diameter of $\mathrm{V}$ containing steels.
ば15), 結晶粒径 $(D)$ は, 第 2 相の粒径 $(d)$ に比 例し，体積率 $(f)$ に反比例する。すなわち $D \propto$ $d / f$ である。いま， $f$ が添加量 (at\%) に比例す

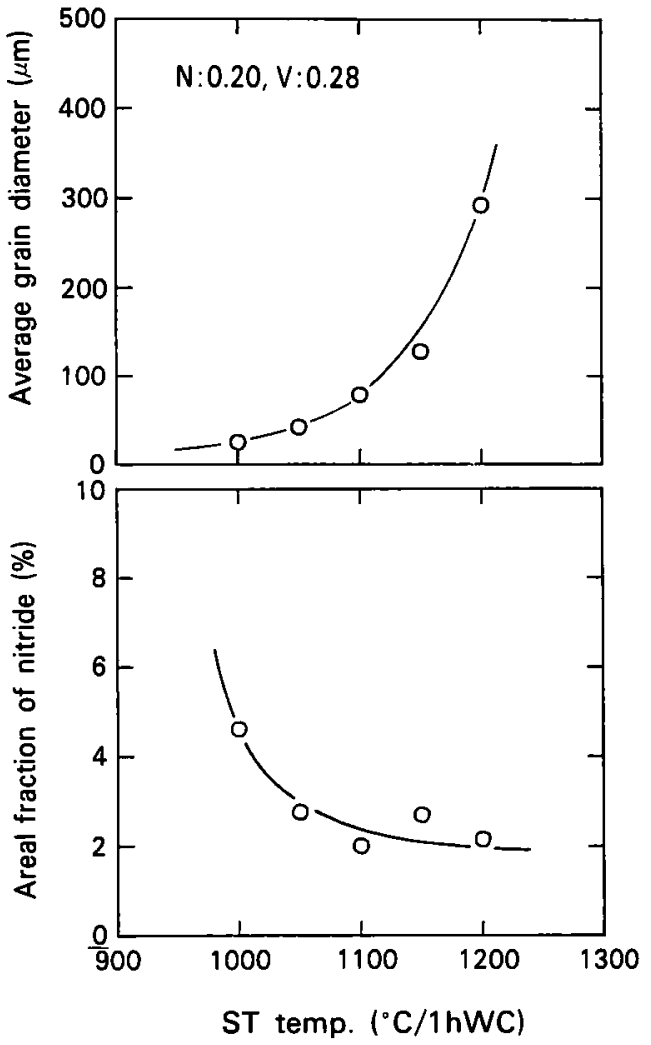

Fig. 2. Areal fraction of retained precipitates after solution treatment.

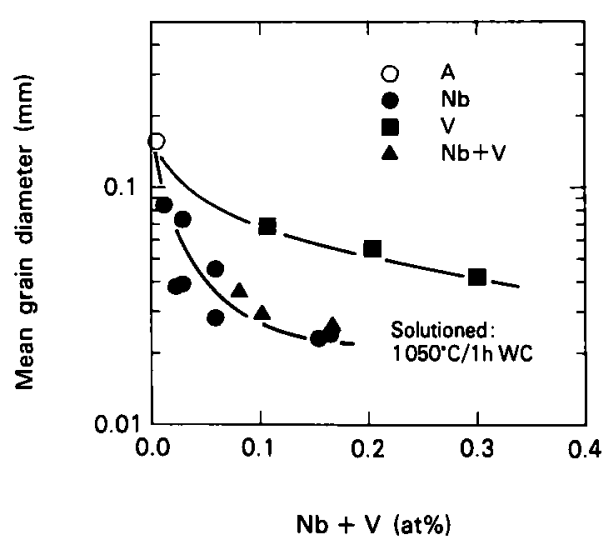

Fig. 3. Effect of $\mathrm{Nb}$ and $\mathrm{V}$ contents on grain diameter. 
ると考えると， $\mathrm{Nb}$ と V の効果の差は， $d$ の相違 すなわち分散状熊の違いによるものと推察され る。

\section{2 固溶化処理材の室温引張特性}

Fig. 4 に固溶化処理材の室温引張特性を示す。 $0.2 \%$ 耐力, 引張強さ共にほ注直線的に上昇し， $\mathrm{N}$ による固溶強化が大きいことを示している。基本 鋼（中印）及び $\mathrm{N}$ 単独添加鋼（申印）は直線上り 低い。これは, 前述の $\mathrm{Nb}, \mathrm{V}$ による結晶粒微細化 が生じていないためである。この Nによる固溶強 化と細粒強化の 2 因子を回帰分析により分離し た。0.2\%耐力 (PS) と引張強さ（TS）に Hall -Petch 型の式を仮定すると次式となる。 $0.2 \% \mathrm{PS}\left(\mathrm{kgf} / \mathrm{mm}^{2}\right)=10.4+75.3 \mathrm{~N}+2.33 \mathrm{D}-\frac{1}{2}$

$$
\mathrm{TS}\left(\mathrm{kgf} / \mathrm{mm}^{2}\right)=46.9+63.5 \mathrm{~N}+2.46 \mathrm{D}^{-\frac{1}{2}}
$$

ここで， $\mathrm{N}$ は $\mathrm{N}$ 含有量 (wt\%)，D は結晶粒径 （mm）である。本研究で得られた $\mathrm{N}$ の固溶強化 の係数は, Pickering 等の 50.3(PS), 86.4(TS)と いら值 ${ }^{16)}$ とほぼー致している。

\section{3 冷間加工材の時効硬化挙動}

（1）時効硬化挙動

$0.2 \mathrm{~N}-0.19 \mathrm{~V}$ 鋼に減面率 $40 \%$ の冷間加工を施 し， Ih 時効した時の硬化曲線を Fig. 5 と 6 に示

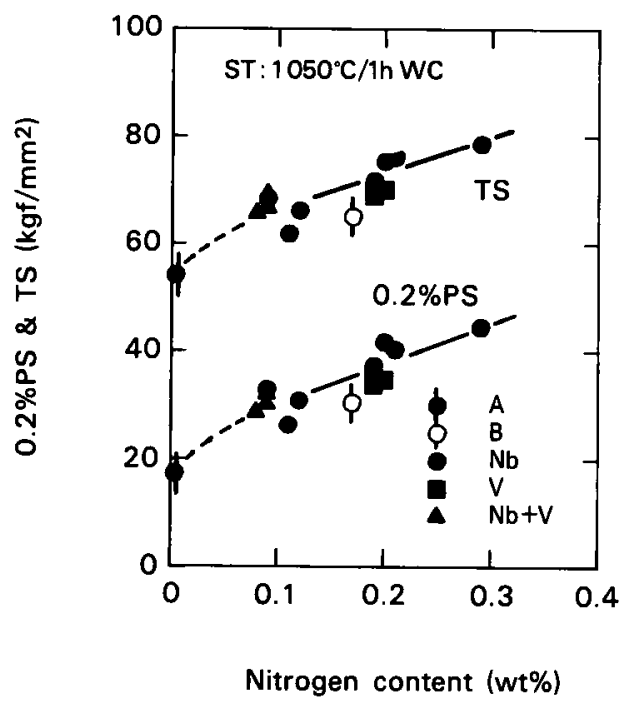

Fig. 4. Effect of nitrogen content on tensile properties.
す。 $500 \sim 600^{\circ} \mathrm{C}$ 硬化のピークが認められる。硬 さと引張強さの上昇が比較的少ないのに対し， $0.2 \%$ 耐力の上昇は著しい。また時効に上る校りの 変化は少なく，延性は劣化しない。Fig.7 は，基本 鋼， $\mathrm{N}$ 単独添加鋼及び $\mathrm{Nb}$ 添加鋼の時効硬化曲線 である。含 $\mathrm{N}$ 鋼は，Nb 添加の有無によらず Fig. 6 の V 添加鋼と同様の顕著な強度上㫒を示すが, $\mathrm{N}$ 無添加の基本鋼は，強度上昇が少ない。すなわ ち，時効硬化は，Nb，Vによらず主に $\mathrm{N}$ 添加によ り生ずる。

Photo 1 は, V 添加鋼の時効によるミク口組織

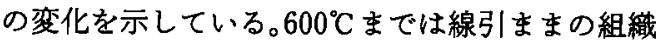

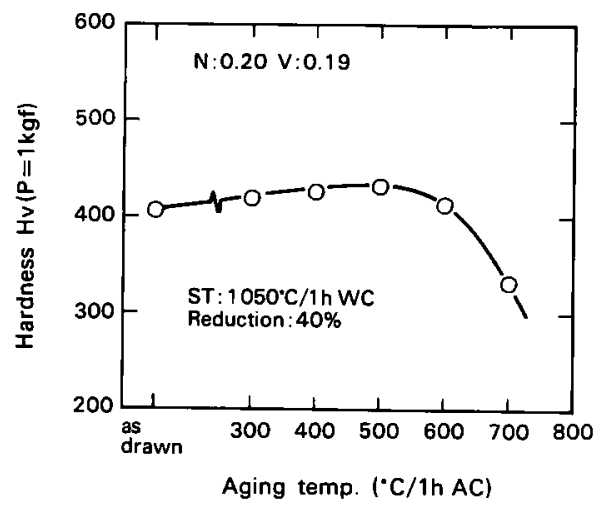

Fig. 5. Age hardening curve of $0.19 \mathrm{~V}-0$. 2N steel. Specimens were cold drawn $40 \%$ and aged for $1 \mathrm{hr}$.

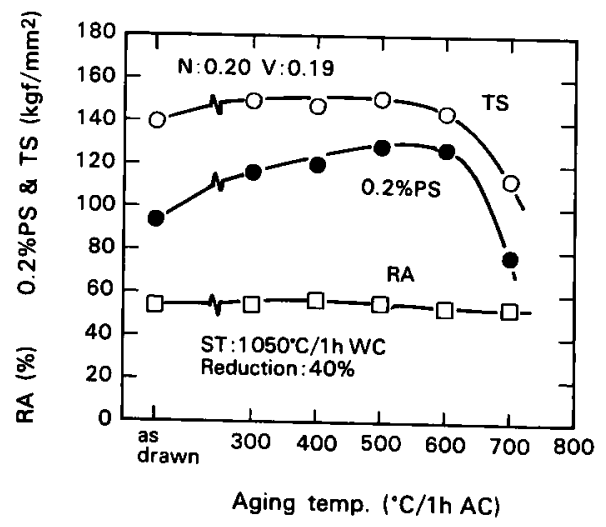

Fig. 6. Effect of aging temperature on tensile properties of $0.19 \mathrm{~V}-0.2 \mathrm{~N}$ steel. Specimens were cold drawn $40 \%$. 


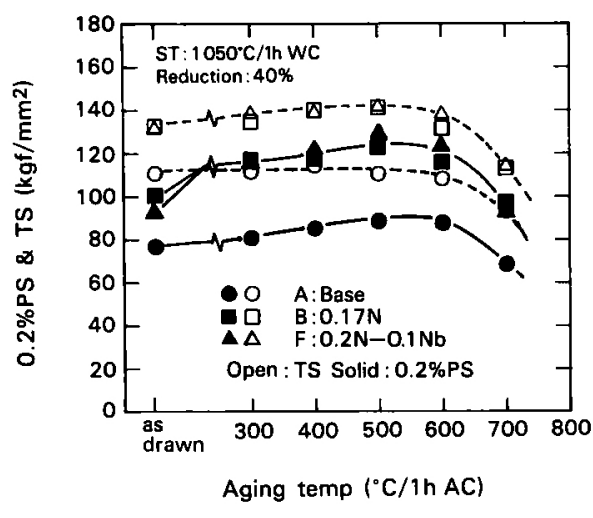

Fig. 7. Comparison of age hardening curves. Steel A:base, B:0.17N, F:0.1Nb $-0.2 \mathrm{~N}$
と差がないが, 700Cにおいては, すべり線及び粒 界が強く腐食され，炭窒化物の析出がかなり生じ

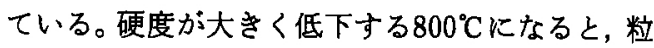
内で再結晶が起こり始めていることがわかる。以 下では，粒界析出が起らず最高強度が得られる $500^{\circ} \mathrm{C} ， 1 \mathrm{~h}$ を時効条件に選び実験を行なった。

(2) 冷間加工の影響

Fig. 8 は，時効硬化に及ぼす冷間加工の影響を 表わす一例である。時効硬化は冷間加工を加えて 初めて生じることがわかる。引張強さの上昇量は， 减面率の増大に伴い単調に増加する。0.2\%耐力の 上昇量は，減面率が低い場合には，減面率と共に 増加する。しかし，減面率が高くなり，線引状態 の耐力が急に上昇すると時効による増加量は飽和 するようになる。これは，強加工により生成した

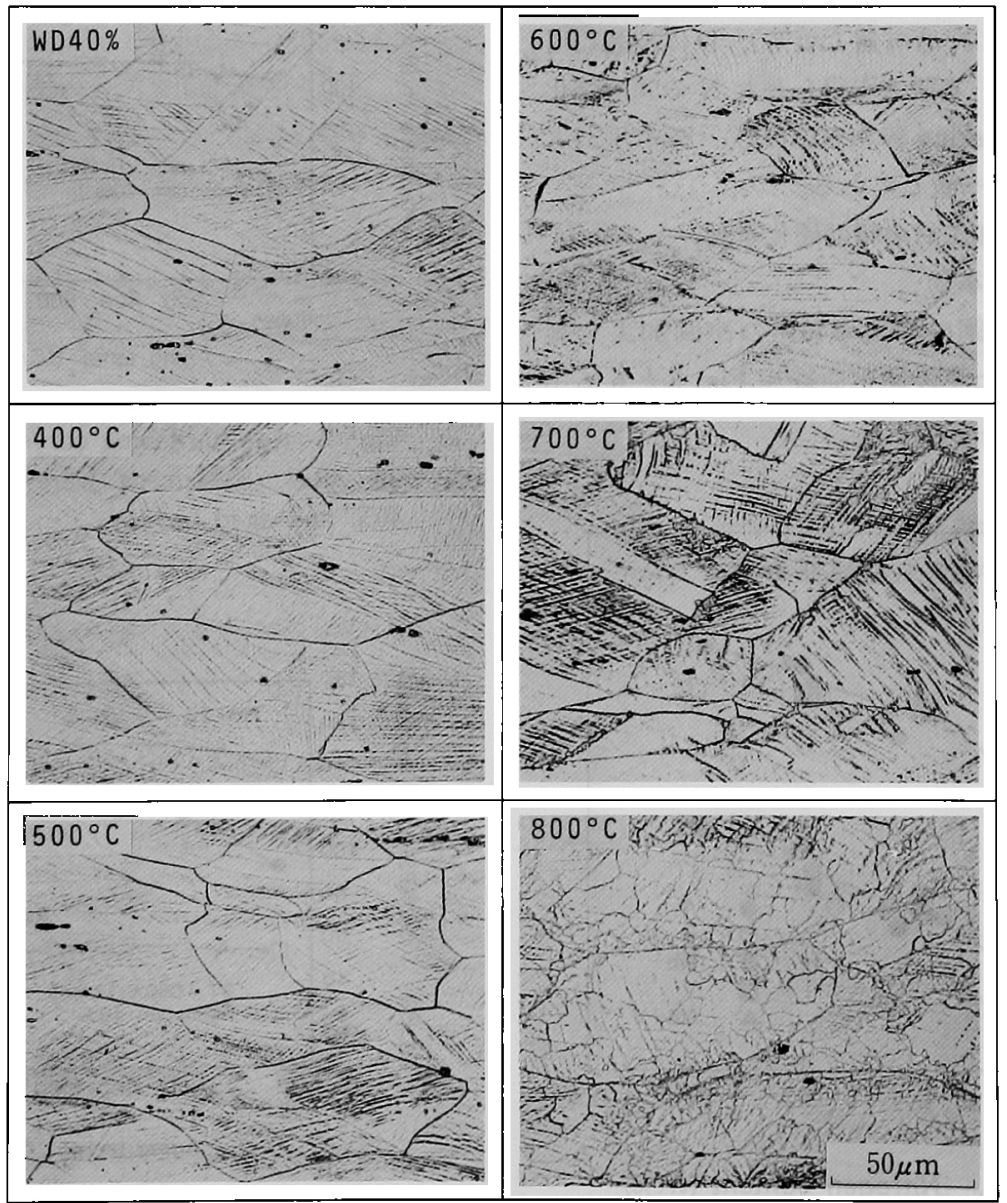

$\mathrm{N}: 0.20, \mathrm{~V}: 0.28$

Photo. 1. Microstructure of aged specimen of $0.19 \mathrm{~V}-0.2 \mathrm{~N}$ steel. 


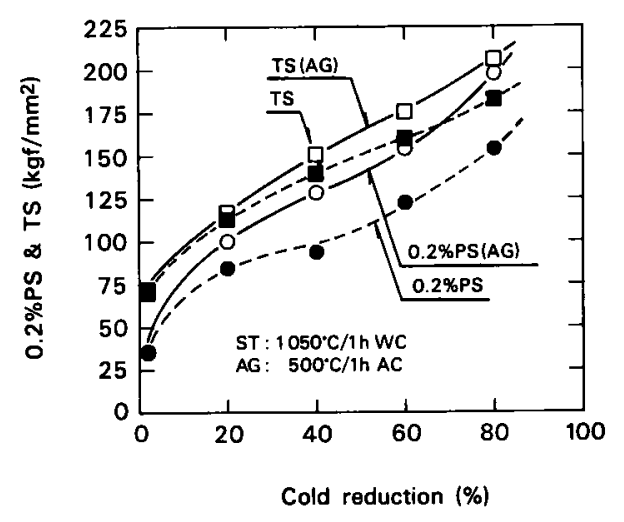

Fig. 8. Effect of cold reduction on age hardening.

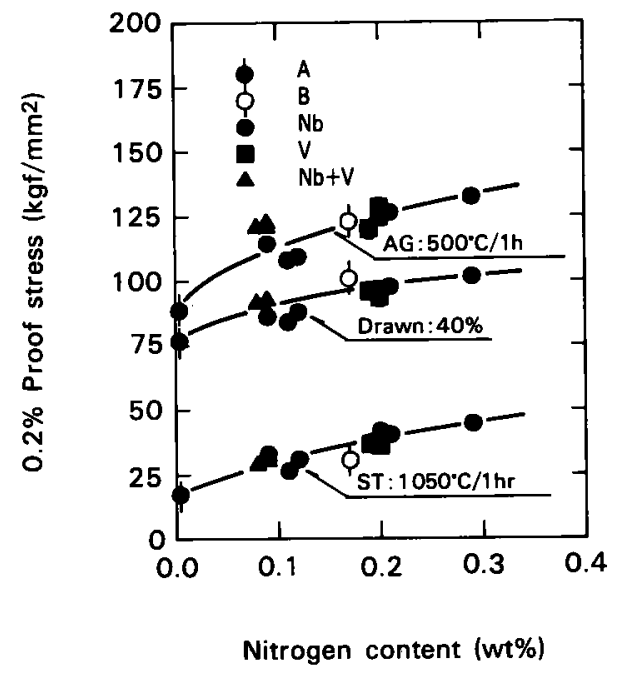

Fig. 9. Effect of nitrogen content on $0.2 \%$ proof stress of aged specimens.

加工誘起マルテンサイトの影響と考えられる。

（3） $\mathrm{N}$ 含有量の影響

Fig. 9 及び 10 に時効材の0.2\%耐力と引張強さ に及ぼす N 含有量の影響を示す。Fig. 11 には，時 効による強度の上昇分をプロットした。強度上昇 は $\mathrm{N}$ 含有量と共に増加し， $0.2 \mathrm{wt} \%$ 以上で飽和す る㑯向を示す。耐力は著しく上昇し，引張強さの 上昇分の 2 倍以上である。

含 $\mathbf{N}$ ステンレス鋼の時奻硬化挙動の特徵は列 挙すると，(1)命間加工が加わって初めて生ずるこ

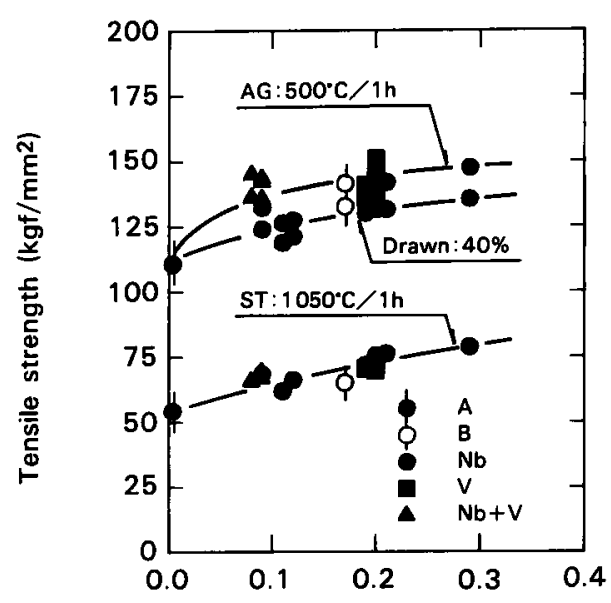

Nitrogen content (wt\%)

Fig. 10. Effect of nitrogen content on tensile strength of aged specimens.
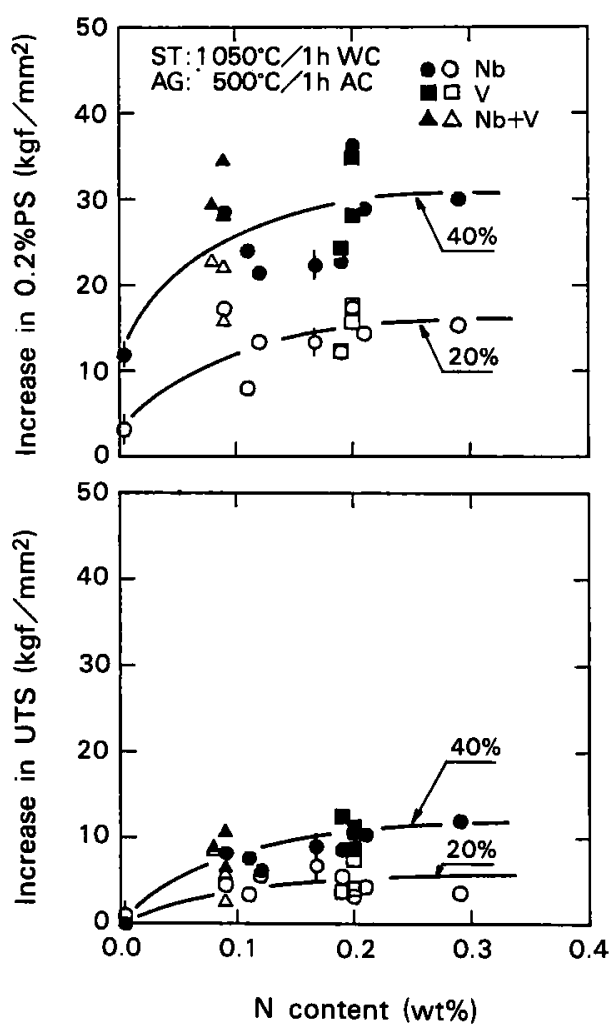

Fig. 11. Increases in $0.2 \%$ proof stress and tensile strength due to age treatment. 


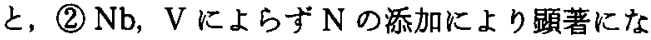
ること,(3)引張強さに比べ0.2\%耐力の上昇が大き いことにある。これらの結果は，含 $\mathrm{N}$ スンンス 鋼の時効硬化が主に冷間加工によって多量に導入 された転位上への炭窒化物の譈細析出により生ず るものであることを示唆している。そこでX 線回 折及び抽出レプリカ観察による析出物の同定を試 みた。

（4）析出物の同定

Table 2 に固溶化処理材及び $500^{\circ} \mathrm{C}$ 時効材より 電解抽出した残渣の X 線回折結果を示す。固溶化 処理状態に括いては, $\mathrm{Nb}$ 添加鋼で $\mathrm{Nb} \mathrm{Cr} \mathrm{N}$ 相が 同定された。この $\mathrm{Nb} \mathrm{Cr} \mathrm{N}$ は，Jack らが Z 相と 名付けた相で17)，他の $\mathrm{Nb}$ 添加含 $\mathrm{N}$ ステンレス鋼
においても認められている ${ }^{12)}$ 。V 添加鋼の固溶化 処理状態の残渣上り得られた回折パターンは，予 想した $\mathrm{VN}, \mathrm{V}_{2} \mathrm{~N}, \mathrm{VC}$ などのパターンとは異なる むので, $\mathrm{Cr}_{2} \mathrm{VC}_{2}$ に類似していた。しかし一致しな い回折線もあり，断定できない。時効処理状態に おいては, 固溶化処理材の析出物に加克て, 回折 強度は小さいが $\mathrm{M}_{23} \mathrm{C}_{6}$ 型の析出物が認められた。 この析出物は時効中に析出し, $\mathrm{M}_{23}(\mathrm{C}, \mathrm{N})_{6}$ の形に なっているすのと思われる。

Photo. 2 に600 $\mathrm{C}$ 時効材の抽出レプリカの透過 電顕写真を示す。 $500^{\circ} \mathrm{C}$ 時効材す観察したが試料の 作製が困難であったので，若干過時効で析出物が 大きい $600^{\circ} \mathrm{C}$ 時効材を観察した。すべり面に沿って 析出したものと思われる微細な析出物が列状に分

Table $2 \mathrm{X}$-ray diffraction data for exracted residues. Interplanar spacing $\mathrm{d}(\mathrm{A})$, relative intensity $I / I_{1}$.

\begin{tabular}{|c|c|c|c|c|c|c|c|c|c|c|}
\hline \multirow{3}{*}{1} & \multicolumn{2}{|c|}{$0.10 \mathrm{Nb}-0.20 \mathrm{~N}$} & \multicolumn{2}{|c|}{$0.19 \mathrm{~V}-0.20 \mathrm{~N}$} & \multirow{2}{*}{\multicolumn{2}{|c|}{$\begin{array}{l}\text { NbCrN } \\
\text { Tetrag. }\end{array}$}} & \multirow{2}{*}{$\begin{array}{c}\mathrm{Nb}(\mathrm{C}, \mathrm{N}) \\
\text { Cubic }\end{array}$} & \multirow{2}{*}{$\begin{array}{c}\mathrm{Cr}_{2} \mathrm{VC}_{2} \\
\text { Orth. }\end{array}$} & \multirow{2}{*}{\multicolumn{2}{|c|}{$\begin{array}{l}\mathrm{Cr}_{23} \mathrm{C}_{6} \\
\text { Cubic }\end{array}$}} \\
\hline & $\mathrm{ST}$ & ST-WD-AG & ST & ST-WD-AG & & & & & & \\
\hline & $2.831 \quad 28$ & $2.821 \quad 27$ & & & 2.80 & & & & & \\
\hline 2 & & & $2.767 \quad 32$ & $2.765 \quad 32$ & & & & & & \\
\hline 3 & & $2.648 \quad 5$ & & $2.676 \quad 11$ & & & & & 2.66 & 30 \\
\hline 4 & $2.550 \quad 9$ & $2.544 \quad 12$ & $2.562 \quad 100$ & 2.560100 & & & $2.58 \quad 100$ & $2.554 \quad 80$ & & \\
\hline 5 & $2.470 \quad 53$ & $2.462 \quad 97$ & & $2.485 \quad 5$ & $2.461 \quad 2$ & & & & & \\
\hline 6 & 2.358100 & 2.349100 & & $2.352 \quad 5$ & $2.344 \quad 5$ & & & $2.326 \quad 60$ & 2.37 & 50 \\
\hline 7 & & & $2.240 \quad 20$ & $2.241 \quad 8$ & & & $2.23 \quad 80$ & $2.208 \quad 20$ & & \\
\hline 8 & & $2.195 \quad 50$ & $2.194 \quad 23$ & $2.193 \quad 6$ & & & & & 2.17 & 50 \\
\hline 9 & $2.158 \quad 59$ & $2.152 \quad 50$ & & $2.162 \quad 5$ & $2.144 \quad 4$ & & & 2.15980 & & \\
\hline 10 & & & $2.118 \quad 27$ & $2.123 \quad 26$ & & & & $2.106 \quad 50$ & & \\
\hline 11 & & & $2.085 \quad 50$ & $2.085 \quad 11$ & & & & 2.081100 & & \\
\hline 12 & & & & $2.060 \quad 5$ & & & & $2.020 \quad 80$ & $2.05 \quad 1$ & 100 \\
\hline 13 & $1.917 \quad 15$ & $1.912 \quad 15$ & & & $1.913 \quad 1$ & & & & & \\
\hline 14 & & $1,890 \quad 4$ & & & & & & & 1.88 & 50 \\
\hline 15 & $\begin{array}{ll}1.848 \quad 10\end{array}$ & $\begin{array}{ll}1.843 & 18\end{array}$ & & & $1.847 \quad 1$ & & & & & \\
\hline 16 & & $\begin{array}{ll}1.797 & 3\end{array}$ & $1.804 \quad 4$ & $1.827 \quad 4$ & & & & & 1.80 & 50 \\
\hline 17 & & & $\begin{array}{ll}1.792 \quad 2 \\
\end{array}$ & $1.787 \quad 2$ & & & & & 1.78 & 40 \\
\hline 18 & $1.620 \quad 15$ & $\begin{array}{|ll|}1.618 & 15 \\
\end{array}$ & $1.633 \quad 23$ & $1.629 \quad 19$ & & & $1.618 \quad 40$ & $1.580 \quad 50$ & 1.61 & 30 \\
\hline 19 & $\begin{array}{ll}1.521 & 10\end{array}$ & $\begin{array}{ll}1.519 & 7 \\
\end{array}$ & & & 1.5183 & & & & & \\
\hline 20 & 1.474 & 1.472 & $1.496 \quad 23$ & $1.496 \quad 26$ & 1.478 & & & & 1.49 & 5 \\
\hline
\end{tabular}




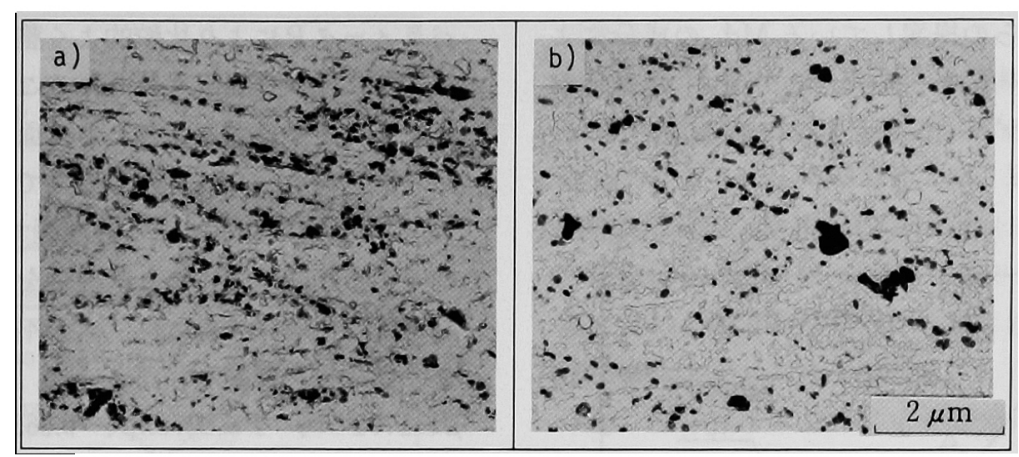

a ) $0.19 \mathrm{~V}-0.20 \mathrm{~N}$

b) $0.10 \mathrm{Nb}-0.20 \mathrm{~N}$

Photo. 2. Transmission electron micrographs of extracted replicas of the specimens aged for 1 h at $600^{\circ} \mathrm{C}$.

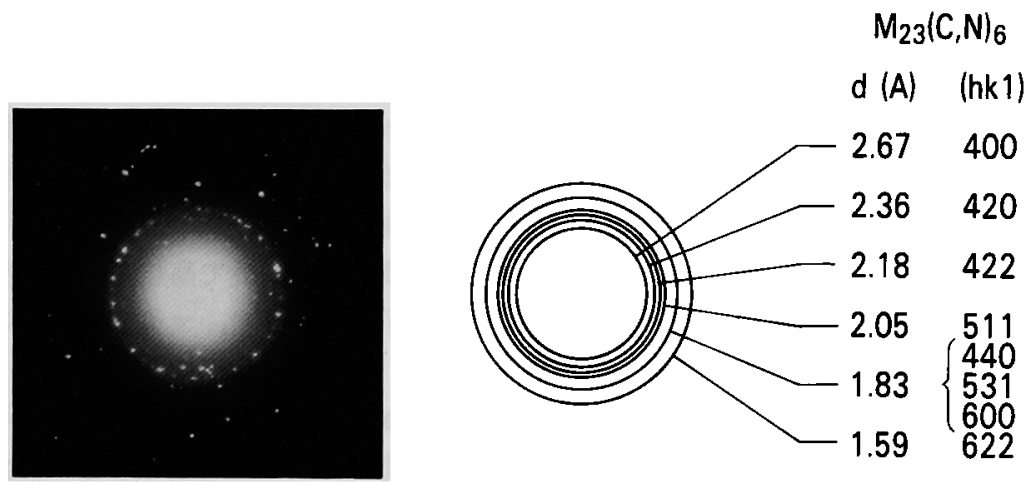

Fig. 12. Electron diffraction pattern of the precipitates observed in extracted replica of $0.1 \mathrm{Nb}-0.2 \mathrm{~N}$ steel.

布している。 $\mathrm{Nb}$ 添加鋼のこのよらな析出物より 採取した電子線回折リングを Fig. 12 に示す。図 中に示したよらに回折リングより求まる面間隔は $\mathrm{M}_{23} \mathrm{C}_{6}$ と一致していた。

以上の結果は, $\mathrm{Nb}, \mathrm{V}$ の炭窒化物が固溶化処理 時に結晶粒成長を抑制し, $\mathrm{M}_{23}(\mathrm{C}, \mathrm{N})_{6}$ 型の崖窒化 物が時効により粒内微細析出して强度を上昇させ ることを裏付けるものと考える。

\section{4 透磁率に及はすすの影暗と非磁性鋼の 合金設計}

オーステナイト系ステンレス鋼は, 冷間加工に より加工誘起マルテンサイトが生成し，透磁率が 上昇する。この透磁率の上昇を抑克，非磁性を確 保するためには Md 点を低くし，加工誘起マルテ
ソサイトの生成を抑制する必要がある。Nはこの Md点を下げるのに極めて有効な元素である。 Fig. 13 に冷間加工材の透磁率と N含有量との関 係を示す。N含有量の増加に伴い透磁率が低下し ている。 $0.05 \mathrm{C}-18 \mathrm{Cr}-10 \mathrm{Ni}$ 系です $0.2 \mathrm{wt} \%$ 以上の Nを添加すれば，減面率40\%の泠間加工を加えて も, 透磁率を1.01以下に維持できることがわかる。 しかし，Nの添加量は製造性等から考えて $0.3 w t \%$ 程度が限界であり, 高减面率の加工を加 える場合には $\mathrm{N}$ 添加のみでは加工誘起マルテン サイトの生成が抑制できない。この場合には成分 の調整が必要となる。そこで従来鋼のデータも加 えて成分バンンスを検討した。

Fig. 14 は,オーステナイトの安定性を表わす指 
標として野原らの提案している $\mathrm{Md}_{30}$ の成分によ る回帰式敫をパラメータ $\mathrm{P}$ とてて用い，各減面率 毎に透磁率をプロットしたものである。透磁率は，

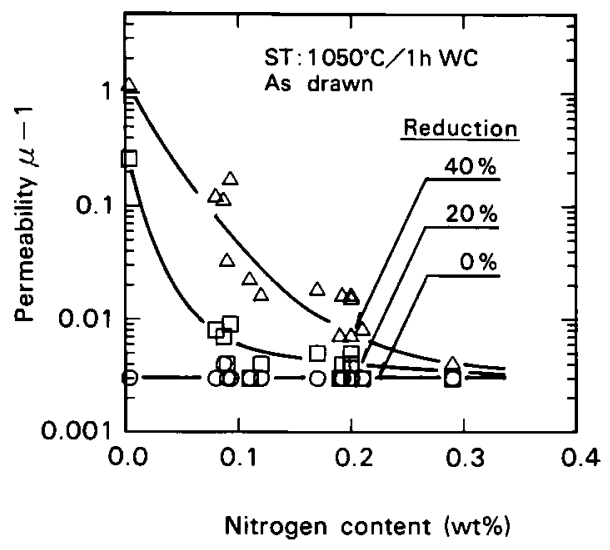

Fig. 13. Effect of nitrogen content on magnetic permeability of cold drawn specimens.

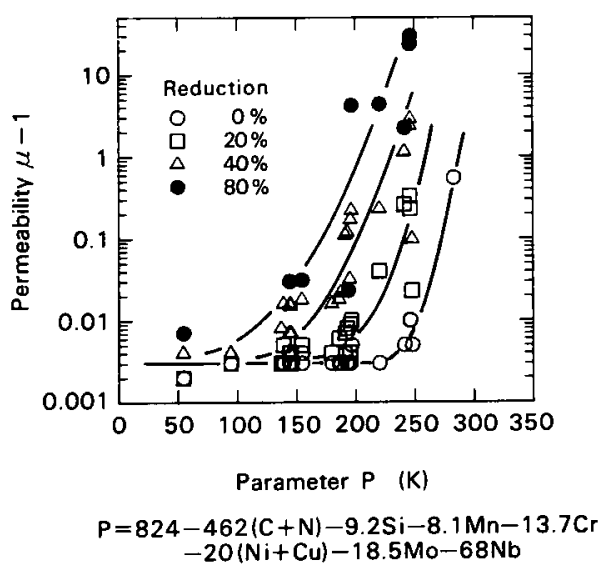

Fig. 14. Magnetic permeability versus parameter P. $\mathrm{P}$ indicates $\mathrm{Md}_{30}$ temperature calculated from the experimental equation proposed by Nohara et al.. ${ }^{14}$
パラメータPにより比較的よく整理でき，Pが低 くなるに従い透磁率む低くなることがわかる。こ れより一定の透磁率を与兄る減面率と $\mathrm{P}$ の值を求 め, $\mathrm{P}=\operatorname{Aexp}(-\mathrm{B} \varepsilon)$ の形の式で回帰した。ここ で, $\varepsilon$ は減面率から求まる塑性昰である。強度等の 要請から泠間加工により塑性歪を与える時, 必要 な透磁率を確保するには，次の不等式を満足する ように成分を調整すればよい。

$$
\mu \leqq 1.01 \text { の時 } \mathrm{P} \leqq 227 \exp (-0.565 \varepsilon)
$$

$\mu \leqq 1.10$ の時 $\mathrm{P} \leqq 254 \exp (-0.239 \varepsilon)$

ここで,

$$
\begin{aligned}
\mathrm{P}= & 824-462(\mathrm{C}+\mathrm{N})-9.2 \mathrm{Si}-8.1 \mathrm{Mn}- \\
& 13.7 \mathrm{Cr}-29(\mathrm{Ni}+\mathrm{Cu})-18.50 \mathrm{Mo}- \\
& 68 \mathrm{Nb}(\text { 各元素共 wt \%) } \\
\varepsilon= & \ln \left(\mathrm{A}_{0} / \mathrm{A}\right)
\end{aligned}
$$

$\mathrm{A}_{0}$ ，A はとれぞれ加工前後の断面積

\section{5 高強度非磁性ステンレス鋼の開発}

これまでの知見に基づき，引張強さが $200 \mathrm{kgf} /$ $\mathrm{mm}^{2}$ 以上, 透磁率1.01以下の非磁性高強度ステン レス鋼を設計・試作した。このような含 $\mathrm{N}$ ステン レス鋼は，非磁性で高強度かつ耐食性が要求され る電子機器部品や，マイクロシャフト類，ステン レスバネなどの用途に適用できる。

Table 3 に供試材の化学組成を示寸。C, N は固 溶強化之時効硬化を考古，Cr は耐食性を，Vは結 晶粒の微細化を考えて設定した。引張強さを 200 $\mathrm{kgf} / \mathrm{mm}^{2}$ とするための減面率を $80 \%$ と仮定する と， $\mu \leqq 1.01$ を満すために必要な $\mathrm{Ni}$ 量は(3)式より 求まり, $\mathrm{Ni} \geqq 11$ wt\%となる。従って, 試作材の $\mathrm{Ni}$ 量は成分の変動等を考え $12 \mathrm{wt} \%$ とした。

Fig. 15 に試作材の機械的性質と透磁率を示す。 $80 \%$ の減面率まで線引き, $500^{\circ} \mathrm{C}, 1 \mathrm{~h}$ の時効を施し た試作材は， $200 \mathrm{kgf} / \mathrm{mm}^{2}$ 以上の引張強さを有す ると共に透磁率は1.01以下を維持している。これ は開発目標を満足するものであり，非磁性鋼の合 金設計を確認するものである。

Table 3 Chemical composition of non-magnetic high strength stainless steel.

(wt \%)

\begin{tabular}{c|c|c|c|c|c|c}
\hline $\mathrm{C}$ & $\mathrm{Si}$ & $\mathrm{Mn}$ & $\mathrm{Ni}$ & $\mathrm{Cr}$ & $\mathrm{V}$ & $\mathrm{N}$ \\
\hline 0.09 & 0.29 & 1.39 & 12.21 & 18.15 & 0.07 & 0.23 \\
\hline
\end{tabular}




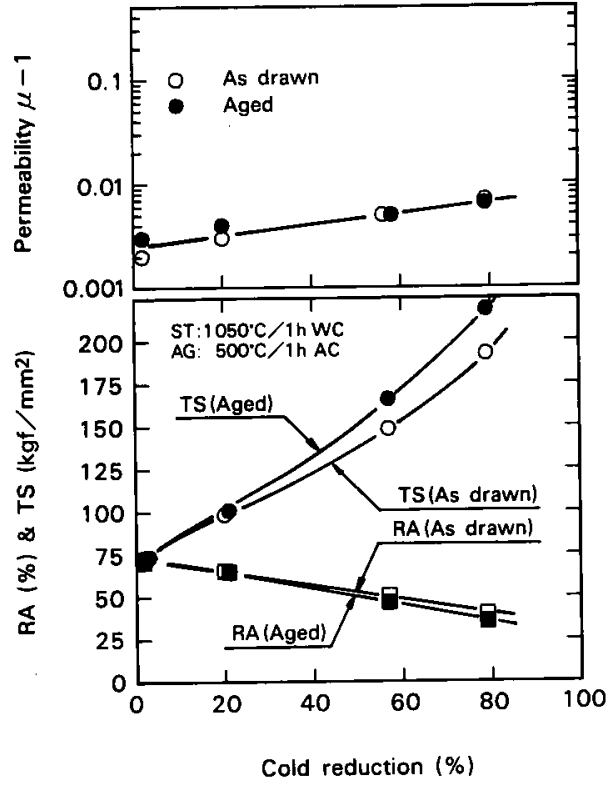

Fig. 15. Tensile properties and magnetic permeability of non-magnetic high strength stainless steel.

\section{4. 結言}

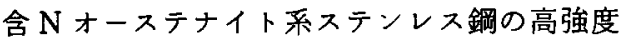
化を計るために，冷間加工を施した $0.05 \mathrm{C}-18 \mathrm{Cr}$ $-10 \mathrm{Ni}$ 系ステンレス鋼において時効硬化挙動に及 ぼす N，Nb，Vの影響を調査した。

同時に冷間加工による透磁率の上昇を抑制する ため透磁率に及ぼす冷間加工量と合金組成の関係 を検討した。その結果，冷間加工後時効すること により引張強さ $200 \mathrm{kgf} / \mathrm{mm}^{2}$ 以上, 透磁率1.01以 下の高強度非磁性ステンレス鋼を開発した。本研 究で得られた結果は以下の通りである。

(1) $\mathrm{Nb}$ まはVをを添加すると固溶化処理時に 炭窒化物により結晶粓成長が抑制され，細粒とな る。この炭窒化物は $\mathrm{Nb}$ 添加鋼では $\mathrm{Nb} \mathrm{Cr} \mathrm{N}$ 相 であり, $\mathrm{V}$ 添加鋼では $\mathrm{Cr}_{2} \mathrm{VC}_{2}$ 相に類似した相で あった。

（2）固溶化処理状態の室温強度は，N の固溶強 化と $\mathrm{Nb}, \mathrm{V}$ による細粒化により大きく上年し，次 式で表わされる。

$0.2 \% \mathrm{PS}\left(\mathrm{kgf} / \mathrm{mm}^{2}\right)=10.4+75.3 \mathrm{~N}+2.33 \mathrm{D}-\frac{1}{2}$

$\mathrm{TS}\left(\mathrm{kgf} / \mathrm{mm}^{2}\right)=46.9+63.5 \mathrm{~N}+2.46 \mathrm{D}-\frac{1}{2}$

ここでNはN含有量 $(\mathrm{wt} \%) ， D$ は結晶粒径 $(\mathrm{mm})$
である。

（3）含Nステンレス鋼を冷間加工後時効する と, $\mathrm{M}_{23}(\mathrm{C}, \mathrm{N})_{6}$ 型の炭窒化物が粒内微細析出して 硬化を生ずる。1 時間時効では， $500 〜 600^{\circ} \mathrm{C} て ゙$ 最 高強度に達し，特に0.2\%耐力の上昇が著しい。こ の時効硬化は，主にNによるもので $\mathrm{Nb} ＼textrm{N}$ は硬 化にはほとんど奇与しない。更に硬化は冷間加工 歪の導入により初めて生じる。

(4) N はオーステナイトを安定にし，加工誘起 マルテンサイトの生成を抑制して，冷間加工材の 透磁率を大きく低下させる。冷間加工材の透磁率 は，組成から $\mathrm{Md}_{30}$ を求める実験式を指標にする と良く整理でき，次の不等式を満すように合金組 成を設定すればよい。

$$
\begin{aligned}
& \mu \leqq 1.01 \text { の場合 } \mathrm{P} \leqq 227 \exp (-0.565 \varepsilon) \\
& \mu \leqq 1.01 \text { 場合 } \mathrm{P} \leqq 245 \exp (-0.239 \varepsilon) \\
& \text { ここで, } \\
& \mathrm{P}=824-462(\mathrm{C}+\mathrm{N})-9.2 \mathrm{Si}-8.1 \mathrm{Mn}- \\
& \quad 13.7 \mathrm{Cr}-29(\mathrm{Ni}+\mathrm{Cu})-18.5 \mathrm{Mo}-68 \mathrm{Nb} \\
& \quad \varepsilon=\ln \left(\mathrm{A}_{0} / \mathrm{A}\right)
\end{aligned}
$$

$A_{0}:$ 冷間加工前の断面積

$A$ ：冷間加工後の断面積

（5）上記知見に基づき， $0.1 \mathrm{C}-18 \mathrm{Cr}-12 \mathrm{Ni}-0.1 \mathrm{~V}$ $-0.25 \mathrm{~N}$ 鋼を試作した。減面率 $80 \%$ の冷間加工後, $500^{\circ} \mathrm{C}, 1 \mathrm{~h}$ 時効することにより，引張強さ $200 \mathrm{kgf} /$ $\mathrm{mm}^{2}$ 以上，透磁率1.01以下の非磁性高強度ステン レス鋼が得られた。

\section{（文献）}

1) K.J. Irvine, D.T. Llewellyn and F.B Pickering : J. Iron Steel Inst., 199 (1961), 153

2) K.J. Irvine, T. Gladman and F.B. Pickering : J. Iron Steel Inst., 207 (1969), 1017

3) B. Holmes and D.J. Dyson: J. Iron Steel Inst., 208 (1970), 469

4) J. Nutting : J. Iron Steel Inst., 207 (1969), 872

5) H.F. Ebling and M.A. Scheil : ASTM STP No. 369 (1965), 275

6) C.S. Tedmon et al. : Corrosion, 27 (1971), 104

7) R. Stickler and A. Vinckier : Trans. ASM, 54 (1961), 362

8) A. Joshi and D.F. Stein : Corrosion, 28 
(1972), 321

9）木内清，近藤達男，鉄と鋼，70（1984）， 112

10）ステンレス鋼便覧（長谷川正義編）：(1973), 479, [日刊工業新聞社]

11）森本一郎，鈴木敏之，土方政行：日本金属学 会誌, 30 (1966), 346

12）椹木義淳, 吉川州彦, 寺西洋志：学振 123 委研 究報告, 24 (1983)，261

13) T. Angel : J. Iron Steel Inst., 177 (1954), 165
14）野原清彦，小野寛，大橋延夫：鉄と鋼, 63 (1977), 212

15) C. Zener: Private Communication, See C. S. Smith : Trans AIME, 175 (1948), 15

16) F.B. Pickering : "Physical Metallurgy and Design of Steels", (1978), 231 〔Applied Science Publisher]

17) D.H. Jack and K.H. Jack: J. Iron Steel Inst., 210 (1972), 790

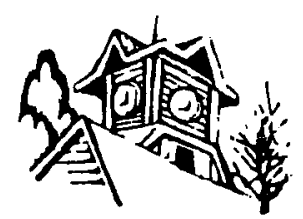

